PERSPEKTIF, 9 (1) (2020): 1-8

DOI: http://dx.doi.org/10.31289/perspektif.v9i1.2582

PERSPEKTIF

Available online http://ojs.uma.ac.id/index.php/perspektif

\title{
Strategi Partai Nasional Demokrat dalam Menghadapi Pemilihan Kepala Daerah Serentak Tahun 2015 Provinsi Sumatera Utara
}

\section{Strategy of the Democratic National Party in Facing the 2015 Simultaneous Local Election of North Sumatra Province}

\author{
Roslinda Wati Malau1), Muhammad Aswin Hasibuan²) \& Irwan Nasution1)* \\ 1) Program Studi Ilmu Pemerintahan, Fakultas Ilmu Sosial Dan Ilmu Politik \\ Universitas Medan Area, Indonesia \\ 2) Fakultas Ushuluddin dan Studi Islam, Universitas Islam Negeri Sumatera Utara, Indonesia
}

Diterima: 27 Mei 2019; Disetujui: 21 September 2019; Diterbitkan: 6 Januari 2020.

\begin{abstract}
Abstrak
Penelitian yang dilakukan oleh peneliti berjudul "Strategi Partai Nasional Demokrat (NasDem) Dalam Menghadapi Pilkada Serentak Tahun 2015 (Studi Pada Dewan Perwakilan Wilayah Partai Nasional Demokrat Provinsi Sumatera Utara". Tujuan penelitian ini bertujuan untuk mengetahui bagaimana strategi partai Nasional Demokrat (NasDem) dalam menghadapi pilkada serentak. Strategi politik merupakan seperangkat metode pendekatan secara keseluruhan yang berkaitan dengan pelaksanaan gagasan, perencanaan agar partai politik dapat memenangkan pertarungan antara berbagai kekuatan politik yang menghendaki kekuasaan dalam Pilkada Serentak. Hal ini merupakan imbas dari proses Reformasi yang terjadi di mana proses politik menjadi lebih berdinamika dan berdemokrasi yang di warnai oleh pertarungan antar partai yang sangat terbuka, hingga akhirnya dibutuhkan adanya strategi politik dengan menggunakan berbagai pendekatan didalamnya termasuk memperhatikan isu politik yang akan dijual kepada kelompok pemilih, memperhitungkan kekuatan sendiri, dan mengamati kemampuan partai pesaing yang menjadi rival politik. Maka dalam penelitian ini akan di lihat bagaimana Partai Nasional Demokrat (NasDem) melakukan berbagai macam hal strategi dalam upayanya memenangkan pertarungan politik pada Pilkada Serentak Tahun 2015 Dewan Perwakilan Wilayah (DPW) di Sumatera Utara sebagai lokasi penelitian penulis. Seberapa kuatkah strategi politik Partai Nasional Demokrat (NasDem) sebagai partai yang berhaluan Nasionalis dengan segala intrument yang ada didalamnya menjawab pertarungan politik yang terjadi, agar mampu memenangkan Pilkada Serentak yang berlangsung pada tanggal 9 Desember 2015, dan serta merta mampu menjadi partai yang disukai dan mengakar didalam mayarakat. Dalam kajian penulis ini akan menggunakan Analisis SWOT, sebagai landasan teoritis untuk mengukur sejauh mana Kekuatan, Kelemahan, Peluang, dan Ancaman yang dihadapi Partai Nasional Demokrat (NasDem). Termasuk bagaimana Partai Nasional Demokrat (NasDem) mengatasi kendala yang dihadapi selama proses penggalangan suara dalam usaha memenangkan Pilkada Serentak Tahun 2015.

Kata Kunci: Strategi, Partai Nasional Demokrat, Pemilihan Kepala Daerah Serentak
\end{abstract}

\section{Abstract}

Research conductedby researchers titled "Strategi Partai Nasional Demokrat (NasDem) Dalam Menghadapi Pilkada Serentak Tahun 2015 (Studi Pada Dewan Perwakilan Wilayah Partai Nasional Demokrat Provinsi Sumatera Utara". The purpose of this study aims to know a strategy of the party Nasional Demokrat (NasDem) in the face of the election simultaneously. A strategy of political is a set of the approach overall related to the implementation of the idea of, planning to a political party can win a fight between a variety of thepower of political process of reform happened where the political process be coming more berdinamika and demokrasi colored by a fight between the very open, until finally neededthe existance of a strategy of political using different approaches in which included noticed a political issue that will be sold to the group voters, take account of the power of her own, and observe the ability of the party of the competitors being political rival. Then in the study this will be seen now the Nasional Demokrat (NasDem) do a variety of things strategy in eforts won a political as the location of the study aut hors. How strong a strategy of political party Nasional Demokrat (NasDem) as the party of the bow of nationalist with all the instruments are there in which answered a political happened, to be able to win pilkada serentak that took place on 9 December 2015 and immediately able to be the preferred and take root in a society. In the study aut hors this will use analysis SWOT, as the theoretically to meausure the extent strength, weakness, the odds, and the threat of faced by the party Nasional Demokrat (NasDem). Including how the Nasional Demokrat (NasDem) tackle obstacles faced during the process of a sound in the effort to win pilkada serentak years 2015.

Keywords : Strategy, The Party Nasional Demokrat (Nasdem), Election Simultaneously.

How to Cite: Malau, R.W. Hasibuan, M.A. \& Nasution, I (2020). Strategi Partai Nasional Demokrat dalam Menghadapi Pemilihan Kepala Daerah Serentak Tahun 2015 Provinsi Sumatera Utara. PERSPEKTIF, 9 (1): 1-8

*Corresponding author:

ISSN 2085-0328 (Print)

E-mail: irwan@staff.uma.ac.id

ISSN 2541-5913 (online) 


\section{PENDAHULUAN}

Di era reformasi pada saat ini, partai politik menjadi perpanjangan tangan rakyat dalam menyalurkan aspirasinya ke pemerintah. Namun pada saat sekarang, peran partai politik di Indonesia sebagai penyambung lidah rakyat tidak terlihat, peran rakyat hanya sebatas memberikan pilihannya pada saat pemilu. Selain itu partai politik juga sering mempertontonkan perilaku politik yang buruk yang membuat rusak demokrasi dan membuat rakyat menjadi antisipasi terhadap partai politik. Hal ini di tandai dengan semakin menurunnya angka partisipasi rakyat terhadap pemilu, baik itu legislatif maupun pemilihan kepala daerah.

Menurut Michael G. Roskin (1997) partai politik berfungsi sebagai alat dalam hubungan rakyat dengan pemerintah, yaitu sebagai mediator antara kebutuhan dan keinginan warga Negara dan responsivitas pemerintah dalam mendengar tuntutan rakyat. Kemampuan partai politik memperjuangkan aspirasi rakyat akan menciptakan kepercayaan masyarakat terhadap keberadaan partai politik didalam institusi pemerintahan.

Menurut Firmanzah (2008) partai politik yang dapat dipercaya rakyat adalah partai yang mampu berinteraksi dengan rakyat secara intensif. Dengan interaksi tersebut, partai politik dapat memahami dan memecahkan permasalahan yang di hadapi masyarakat.

Istilah strategi dalam kamus bahasa Indonesia di artikan sebagai rencana yang cermat mengenai kegiatan untuk mencapai sasaran khusus. Menurut steinberg yang di kutip oleh Venus, strategi di artikan sebagai rencana untuk tindakan, penyusunan dan pelaksanaan strategi mempengaruhi sukses atau gagalnya strategi pada akhirnya. Liddle hart berpendapat bahwa ada beberapa asensi dari strategi antara lain ebagai berikut. (Venus, 2004): 1) Atur tujuan sesuai dengan makud; 2) Selalu tetapkan sasaran dalam pikiran; 3) Pilih harapan yang paling mungkin; 4) Berani melawan yang paling mungkin untuk di lawan; 5) Ambil arah operasi yang menawarkan alternatif obyektif; 6) Pastikan bahwa antara rencana dan formasi strategi sifatnya fleksibel dan adaptif dengan waktu dan keadaan mendadak.

Krisis kepercayaan masyarakat terhadap partai politik bersumber dari gagalnya partai politik dalam dalam melakukan proses rekrutmen dan kaderisasi. Sehingga yang akhirnya tampil di panggung politik adalah orang-orang yang tidak jelas kapasitas serta moralnya (Suharyanto, 2014). Bagi masyarakat partai politik tidak bermanfaat positif untuk perbaikan bangsa dan Negara, justru merusak tatanan hukum dan demokrasi serta menciptakan kondisi politik yang tidak beraturan.

Sudah seharusnya setiap partai politik wajib memiliki strategi untuk dapat mendulang suara yang signifikan dari konstituen, dengan konsep pemenangan yang terfokus guna untuk memenangkan partainya, baik melalui pengorganisasian dan konsolidasi kader, penguasaan terhadap kondisi objektif yang ada dalam areal pertarungan politik.

Sejak bergulirnya era reformasi yang membuka keran terhadap proses demokrasi, dimana setiap partai politik berkompetisi dalam setiap pemilu dan memiliki peluang untuk memenangkan pertarungan politik dalam pemilu. Reformasi menjadikan proses politik menjadi lebih berdinamika, yang di warnai oleh pertarungan antar partai yang sangat terbuka, hingga akhirnya di butuhkan adanya strategi politik untuk memenangkan hati masyarakat dan meraih simpati konstituen sebagai penentu dari suatu kepetusan politik dengan menggunakan berbagai pendekatan termasuk memperhatikan isu politik yang di jual kepada kelompok pemilih, dan mengamati kemampuan partai pesaing yang menjadi rival politik.

Sementara itu untuk mempersiapkan diri menuju pilkada serentak tahun 2015, salah satu partai yang tertarik untuk dianalisis yakni Partai Nasional Demokrat (NasDem) (Nasional Demokrat), karena Partai Nasional Demokrat (NasDem) merupakan partai baru yang secara resmi lolos verifikasi oleh Komisi Pemilihan Umum (KPU) yang nantinya akan ikut bertarung dalam pemilu 2014. Pasalnya, hari itu KPU mengumumkan hasil verifikasi faktual dan menyatakan Partai Nasional Demokrat (NasDem) lolos dalam memenuhi persyaratan verifikasi factual 35 Buku Pegangan Partai Nasional Demokrat (NasDem).

Di dalam pemaparan selanjutnya penulis akan mencoba menggambarkan bagaimana strategi yang dilakukan partai Nasional Demokrat (NasDem) untuk mendulang suara 
yang signifikan dari konstituennya, hingga akhirnya orang-orang yang menjadi calon legislatif dari partai Nasional Demokrat (NasDem) menang dalam pilkada serentak 2015.

\section{METODE PENELITIAN}

Dalam penelitian ini metode yang digunakan adalah pendekatan kualitatif yang bersifat deskriptif. Menurut Kurt dan Militer Moleong (2004) "penelitian kualitatif adalah tradisi tertentu dalam ilmu pengetahuan social yang secara fundamental bergantung pada pengamatan manusia dalam kawasannya sendiri dan berhubungan dengan bahasan dan dalam peristilahannya". Metode kualitatif merupakan metode penelitian yang di gunakan untuk meneliti pada kondisi objek yang alamiah, dimana peneliti adalah sebagai instrumen kunci teknik pengumpulan data secara gabungan. Dengan metode penelitian kualitatif dalam penelitian ini bertujuan untuk memberikan suatu bentuk pemahaman tentang relita social sehingga dapat memberikan suatu pengaruh terhadap masyarakat sekitar.

Peneliti yang bersifat deskriptif ini dapat di gunakan pada penelitian yang memerlukan pengungkapan tentang fenomena social secara mendalam. Seperti yang di ungkapkan oleh Nazir (2003) "penelitian deskriptif mempelajari tentang masalah-masalah didalam partai politik, serta tata cara yang berlaku dalam masyarakat serta stuasi tertentu, termasuk tentang hubunganhubungan, kegiatan-kegiatan, sikap-sikap, pandangan-pandangan, serta proses yang sedang berlangsung dan pengaruh-pengaruh dari suatu fenomena".

Penggunaan metode penelitian menggunakan pendekatan kualitatif yang bersifat deskriptif ini dengan alasan untuk menggali dan mengungkapkan fenomena social dalam Strategi Partai Nasional Demokrat (NasDem) dalam pengkaderan pemilukada di SUMUT.

Informan adalah seseorang yang benarbenar mengetahui suatu persoalan atau permasalahan tertentu yang dapat diperoleh informasi yang jelas, akurat dan terpercaya baik berupa pertanyaan, atau data-data yang dapat membantu dalam memenuhi persoalan atau permasalahan.
Adapun informan penelitian ini ialah : Informan kunci yaitu mereka yang mengetahui dan memiliki berbagai informasi pokok yang diperlukan dalam penelitian. Adapun informan kunci dalam penelitian ini adalah Ketua Partai Nasional Demokrat (NasDem) Bapak Tengku Erry Nuradi. Informan tambahan yaitu mereka yang memberikan informasi walaupun tidak terlibat didalam interaksi sosial yang diteliti. Adapun informan tambahan dalam penelitian ini adalah para pengurus partai Nasional Demokrat (NasDem) di Sumatera Utara.

Sumber data dalam penelitian ini ada dua yaitu data primer dan data sekunder. Data primer adalah data yang diperoleh peneliti secara langsung (langsung dari tangan pertama), yakni data yang berupa hasil wawancara dengan informan selain itu ada data yang diperoleh dari lapangan (srategi Partai Nasional Demokrat (NasDem) dalam menghadapi Pilkada Serentak). Sementara data sekunder adalah data yang diperoleh peneliti dari sumber yang sudah ada, yakni data literature yang mendukung data primer seperti buku catatan atau dokumentasi dari instansi berupa absensi, laporan keuangan dan lain-lain.

Teknik pengumpulan data yang digunakan penulis dalam penelitian ini adalah teknik wawancara, dokumentasi, dan observasi. Wawancara adalah percakapan atau tanya jawab yang diarahkan dengan tujuan tertentu. Wawancara dilakukan oleh dua pihak yaitu pewancara (interviewer) yang mengajukan pertanyaan dari yang di wawancarai (interviwed) yang memberikan jawaban. Teknik yang digunakan adalah metode interview, di mana peneliti mengajukan pertanyaan-pertanyaan yang telah di persiapkan kemudian langsung di jawab oleh informan. Dalam hal ini di lakukan peneliti untuk menggali informasi dan data yang akurat dari informan yang berkaitan dengan Bagaimana kondisi Sumatera Utara pada saat berlangsungnya penyelenggaraan pilkada serentak. "Bagaimana persiapan partai Nasional Demokrat dalam menghadapi pilkada serentak di Sumatera Utara Tahun 2015".

Dokumentasi adalah satu metode pengumpulan data dengan cara melakukan analisis terhadap semua catatan dan dokumen yang di miliki organisasi yang di pilih sebagai objek penelitian atau data individu dari objek penelitian. Dalam hal ini penulis 
mengumpulkan data yang berkaitan tentang Bagaimana persiapan partai Nasional Demokrat dalam menghadapi pilkada serentak di Sumatera Utara.

Obervasi yaitu peneliti melakukan kegiatan pengamatan secara langsung pada objek penelitian dan di bantu dengan pencatatan fenomena yang di temukan di lapangan. Observasi yang di lakukan peneliti non partisipasi di mana observasi yang dalam pelaksanaannya tidak melibatkan peneliti sebagai partisipasi atau kelompok yang diteliti.

Analisis data dalam penelitian kualitatif deskriptif dilakukan sejak sebelum memasuki lapangan, selama dilapangan dan setelah selesai dilapangan dalam Sugiyono, (2008). Dengan demikian, penelitian ini mengikuti langkah-langkah seperti yang dianjurkan oleh Miles dan Huberman Sugiyono, (2008) yaitu: (1) reduksi data, (2) display data, dan (3) pengambilan kesimpulan dan verifikasi.

Pemeriksaan kelengkapan dan kesempurnaan data, serta kejelasan data. Memilah data yang diperoleh untuk dijadikan bahan laporan penelitian. Tujuannya agar data yang didapatkan sesuai dangan masalah penelitian.

Penyajian data dengan cara menggelompokan atau mengklasifikasi data dan dipilih sesuai dengan jenisnya. Klasifikasi data ini dilakukan untuk memberikan batasan pembahasan dan berusaha untuk menyusun laporannya secara sistematis.

Menginterpretasikanapa yang telah diberikan dan diinterpretasikan oleh informan terhadap masalah yang diteliti. Pengambilan kesimpulan berdasarkan susunan narasi yang telah disusun sebelumnya sehingga dapat memberikan jawaban atas masalah penelitian. Melakukan verifikasi hasil analisis data dengan informan didasarkan pada kesimpulan yang dihasilkan. Tahap ini menginterpretasikan dari hasil wawancara dengan informan penelitian.

\section{HASIL DAN PEMBAHASAN}

Para pendiri partai Nasional Demokrat (NasDem) menyadari pada saat lahirnya reformasi tidak menawarkan arah yang jelas kemana bangsa ini akan dituju. Kemerdekaan 17 Agustus tahun 1945 meletakkan dasar penting lahirnya sebuah bangsa besar, Bangsa Indonesia. Negara ini diadakan untuk menjalankan mandat yang tertuang dalam konstitusi UUD 1945 (Undang-Undang Dasar tahun seribu sembilan ratus empat puluh lima), mandat untuk menjadikan manusia Indonesia yang hidup adil, makmur dan sejahtera. Merdeka sebgai negara, merdeka sebagai rakyat. Merdeka yang kami maksud berarti kebutuhan rakyat yang terpenuhi, tidak hanya berhenti sebagai jagoan-jagoan politik, indah di dengar namun tak pernah terwujud. Di sinilah negara Indonesia yang merdeka memiliki kewajiban untuk menjamin terpenuhinya hak dan kebutuhan rakyatnya, termasuk melindungi jika hak-hak itu di langar.

Pendiri partai Nasional Demokrat (NasDem) sangat bersyukur karena reformasi telah mengeluarkan kita dari kubangan kediktatoran. Demokrasi terjebak dalam prosedur-prosedur yang tidak berkonstribusi langsung pada kesejahteraan rakyat. Demokrasi berjalan tanpa bimbingan ideologi politik, tanpa program politik yang konsisten, dan pada akhirnya menjauhkan negara dari mandat konstitusionalnya. Pendiri partai Nasional Demokrat (NasDem) menolak demokrasi yang hanya sekedar merumitkan tata cara berpemerintahan tanpa mewujudkan kesejahteraan umum. Pendiri partai Nasional Demokrat (NasDem) menolak demokrasi yang hanya menghasilkan rutinitas sirkulasi kekuasaan tanpa kehadiran pemimpin yang berkualitas dan layak diteladani. Kami menolak demokrasi tanpa orientasi pada publik. Kami menolak negara yang meninggalkan perannya dalam pemenuhan hak warga negara.

Pendiri partai Nasional Demokrat (NasDem) mencita-citakan demokrasi Indonesia yang matang, yang menjadi tempat persandingan keberagaman dengan kesatuan, dinamika dengan ketertiban, kompetisi dengan persamaan, dan kebebasan dengan kesejahteraan. Pendiri partai Nasional Demokrat (NasDem) mencita-citakan sebuah demokrasi berbasis warga Negara yang kuat, yang terpanggil untuk merebut masa depan yang gemilang, dengan keringat dan tangan sendiri. Pendiri partai Nasional Demokrat (NasDem) berdiri atas nama gagasan sosial demokrasi yang mengedepankan kehadiran negara dalam pemenuhan hak warga negara dan berdiri untuk membangun politik warga Negara berdasarkan cita-cita kesejahteraan, kesetaraan dan gotong royong. 
Partai Nasional Demokrat (NasDem) berdiri untuk merestorasi cita-cita Republik Indonesia. Kami mengusung mandat konstitusi untuk membangun sebuah Negara kesejahteraan berdasarkan prinsip demokrasi ekonomi, negara hukum yang menjungjung tinggi hak asasi manusia, dan negara yang mengakui keberagaman sesuai prinsip Bhinneka Tunggal Ika.

Partai Nasional Demokrat (NasDem) lahir sebagai sebuah keseharusan sejarah. Kami lahir dari pergulatan pemikiran para pendiri bangsa dan lahir sebagai jawaban atas kekosongan politik gagasan pasca reformasi. Kami berdiri tegak dengan semangat kebangsaan yang kuat untuk mewujudkan Indonesia yang adil, makmur, sejahtera dan berdaulat.

Partai Nasional Demokrat (NasDem) adalah perwujudan dari Nasionalisme kebangsaan, kedaulatan nasional yang bertumpu pada masyarakat yang Sejahtera, kekuatan Demokratik seluruh komponen bangsa, kemandirian Ekonomi, dan negara bangsa yang memiliki martabat dalam pergaulan Internasional.

Berdasarkan dari wawancara yang telah di lakukan oleh peneliti, maka peneliti memaparkan mengenai Strategi Partai Nasional Demokrat (NasDem) dalam menghadapi Pilkada Serentak 2015 di DPW Partai Nasional Demokrat Provinsi Sumatera Utara.

Dalam sejarah sistem perekrutan pemilihan kepala daerah sejak Indonesia merdeka, kita sudah mengeluarkan cukup banyak peraturan yang mengatur tentang pemilihan kepala daerah. Undang-undang No 8 Tahun 2015 yang mengatur tentang pemilihan kepala daerah yang di laksanakan secara serentak. Oleh karena itu, sekarang adalah era pelaksanaan pemilihan kepala daerah secara langsung. Maka dalam hal ini pembahasannya lebih di fokuskan kepada strategi yang lebih di lakukan Partai Nasional Demokrat (NasDem) dalam menghadapi Pilkada Serantak tahun 2015.

Adapun strategi yang dilakukan Partai Nasional Demokrat (NasDem) dalam menghadapi pilkada serentak tahun 2015 yaitu: 1) Melakukan penguatan infrasruktur di semua tingkatan partai seperti DPW, DPD, DPC, DPRt guna untuk memperbaiki dan membenahi infrastruktur yang ada di
Indonesia. 2) Melaksanakan konsolidasi yang kontiniue untuk menyampaikan programprogram yang di lakukan Partai Nasional Demokrat (NasDem) mulai dari tingkat tertinggi hingga ketingkat terendah, guna untuk memaksimalkan struktur partai; 3) Meningkatkan kualitas pembangunan melalui program pendidikan, kesehatan, sosial dan budaya serta olahraga; 4) Menyiapkan kader dengan kualitas kinerja yang baik guna untuk melihat seberapa jauh kedekatan para kinerja kader di tengah-tengah masyarakat dalam melakukan kegiatan-kegiatan sosial; 5) Dengan perkembangan teknologi saat ini isuisu yang terjadi di Indonesia harus lebih jeli dan peka supaya partai Nasional Demokrat (NasDem) dapat memberikan solusi; 6) Melakukan pendekatan kepada masyarakat dengan cara memberikan pandangan moral yang baik, nilai-nilai positif agar tercipta kesejahteraan rakayat Indonesia yang adil, makmur, dan berdaulat; 7) Melakukan pembentukan para kinerja kader yang bebas dari korupsi guna untuk kesejahteraan masyarakat indonesia yang bersih; 8) Pembentukan klinik guna untuk melayani dan memberikan fasilitas kepada masyarakat.; 9) Pembentukan dalam membuat kartu anggota dalam bentuk asuransi pada akhir hidupnya, yang mendapatkan kartu asuransi tersebut dimulai dari usia 50 tahun keatas dan pada saat dia meninggal akan mendapatkan uang sebesar 1.000.000;00 rupiah. Untuk mengurus ini tidak di pungut mahar/gratis. Sumber (hasil wawancara dengan wakil sekretaris DPW Nasional Demokrat (NasDem) oleh pak Ganda Manurung tanggal 26 Mei 2015 pukul $16: 30$ wib); 10) Melakukan konsolidasi ke DPRD partai itu dan melihat survei turun kelapangan langsung untuk meningkatkan strategi agar selalu bisa dipertahankan agar tidak menurun. Sumber (hasil wawancara dengan wakil sekretaris DPW Nasional Demokrat (NasDem) oleh pak Ganda Manurung tanggal 26 Mei 2015 pukul 16:30 wib); 11) Menggerakkan kader partai anggota DPRD untuk membantu pasangan calon yang didukung oleh partai Nasional Demokrat (NasDem) dan melakukan kegiatan-kegiatan sosial agar dapat merebut hati pemilih dalam bentuk pengobatan gratis, bantuan gratis, gotong royong, sosialisasi kesehatan (tidak berbentuk barang). Sumber (hasil wawancara dengan tim sukses Pilkada serentak 9 
Desember 2015 DPW Nasional Demokrat (NasDem) oleh pak Anderson King Junior tanggal 26 Mei 2015 pukul 16:30 wib).

Berdasarkan uraian di atas mengenai strategi yang di lakukan partai Nasional Demokrat (NasDem). Maka pemilihan kepala daerah yang di selenggarakan untuk menyeleksi para calon pemimpin di daerah

Tabel 4.2 Pemungutan Suara Partai Nasional Demokrat (NasDem) Dalam Pilkada Serentakdi DPW Sumatera Utara Tahun 2015

\begin{tabular}{|c|c|c|c|c|c|c|}
\hline No & Kab/Kota & $\begin{array}{l}\text { No } \\
\text { Urut }\end{array}$ & $\begin{array}{l}\text { Nama Pasangan } \\
\text { calon }\end{array}$ & $\begin{array}{l}\text { Partai } \\
\text { Pendukung }\end{array}$ & $\begin{array}{l}\text { Perolehan suara } \\
9 \text { Des } 2015\end{array}$ & $\begin{array}{l}\text { Perolehan suara } \\
10 \text { Des } 2015\end{array}$ \\
\hline & $\begin{array}{l}\text { Kota } \\
\text { Medan } \\
2,013,934\end{array}$ & 1 & $\begin{array}{l}\text { DRS. H. Dzulmi } \\
\text { Eldin S, M. Sii-Ir. } \\
\text { Akhar Nasutioan, } \\
\text { M. Si (PDIP) }\end{array}$ & $\begin{array}{l}\text { PDIP, PKS, PKPL, } \\
\text { Nasional } \\
\text { Demokrat } \\
\text { (NasDem), } \\
\text { Golkar \& PBB }\end{array}$ & 307,879 & $72,32 \%$ \\
\hline & $\begin{array}{l}\text { Serdang } \\
\text { Bedagai } \\
482,934\end{array}$ & 4 & $\begin{array}{l}\text { Ir. H. Soekirman } \\
\text { (PAN)-Darma } \\
\text { Wijaya }\end{array}$ & $\begin{array}{l}\text { PAN, Demokrat, } \\
\text { Gerindra, PKB, } \\
\text { Nasional } \\
\text { Demokrat } \\
\text { (NasDem) }\end{array}$ & $52,20 \%$ & $99,173 / 29,39 \%$ \\
\hline & $\begin{array}{l}\text { Toba } \\
\text { samosir } \\
134,284\end{array}$ & 1 & $\begin{array}{l}\text { Ir. Darwin } \\
\text { Siagiaan-Ir. } \\
\text { Hulman Sitorus, } \\
\text { MMA }\end{array}$ & $\begin{array}{l}\text { Nasional } \\
\text { Demokrat } \\
\text { (NasDem), } \\
\text { Hanura, \& PDIP }\end{array}$ & 39,052 & 39,690 \\
\hline & Samosir & 3 & $\begin{array}{l}\text { Drs. Raun } \\
\text { Sitanggang MM- } \\
\text { Ir. Pardamean } \\
\text { Gultom }\end{array}$ & $\begin{array}{l}\text { Partai Nasional } \\
\text { Demokrat } \\
\text { (NasDem) \& PKB }\end{array}$ & $22,00 \%$ & $14,496 / 22 \%$ \\
\hline
\end{tabular}

Sumber: Pemungutan Suara Partai Nasional Demokrat (NasDem) Dalam Pilkada Serentak di DPW Sumatera Utara Tahun 2015

Berdasarkan uraian di atas dapat di ketahui mengenai hasil perolehan suara di Provinsi Sumatera Utara pada Partai Nasional Demokrat (NasDem) di pereroleh dengan angka tertinggi oleh Kota Medan dengan 73,32\%.

Pemilihan umum kepala daerah (PEMILUKADA) yang bersifat langsung adalah sebuah pemilihan umum pada skala daerah (lokal) untuk dapat memilih pemimpin publik pada jabatan Gubernur di tingkat Provinsi serta jabatan Bupati di setiap Kabupaten atau jabatan Walikota bagi di tiap-tiap kota. Setiap daerah Provinsi memiliki agenda tersendiri dalam persoalan waktu untuk melaksanakan pemililihan tersebut yang sesuai dengan kondisi tiap-tiap daerah Provinsi di Indonesia.

\section{Analisis SWOT}

Analisis SWOT adalah metode perencanaan strategi yang digunakan untuk mengevaluasi kekuatan (strengths), kelemahan (weaknesses), peluang (opportunities), dan ancaman (threats) dalam suatu proyek atau tidak terlepas dari peran partai politik sebagai penghubung antara rakyat di satu pihak dan pemerintah di pihak lain. Adapun hasil dari perolehan suara pada Pilkada Serentak 9 Desember 2015 yang diperoleh Partai Nasional Demokrat (NasDem) adalah : suatu spikulasi bisnis. Keempat faktor itulah membentuk akronim SWOT (strengths, weaknesses, opportunities, dan threats). Proses ini melibatkan penentuan tujuan yang spesifik dari spikulasi bisnis atau proyek dan mengidentifikasi faktor internal dan eksternal yang mendukung dan yang tidak mencapai tujuan tersebut.

Analisis SWOT dapat diterapkan dengan cara menganalisis dan memilah berbagai hal yang mempengaruhi keempat faktornya, kemudian menerapkannya dalam gambar matrik SWOT, di mana aplikasinya adalah bagaimana kekuatan (strengths) mampu mengambil keuntungan (advantage) dari peluang (opportunities) yang ada, bagaimana cara mengatasi kelemahan (weaknesses) yang mencegah keuntungan (advantage) dari peluang (opportunities) yang ada, selanjutnya bagaimana kekuatan (srengths) mampu menghadapi ancaman (threats) yang ada, dan terakhir adalah bagaimana cara mengatasi kelemahan (weaknesses) yang mampu 
membuat ancaman (threats) menjadi nyata atau menciptakan sebuah ancaman baru.

Hasil analisis penulis dalam penelitian mengenai Kekuatan yang di lakukan peneliti di lapangan antara lain sebagai berikut: 1) Adapun kekuatan partai Nasional Demokrat (NasDem) dalam menghadapi pilkada serentak 9 Desember Tahun 2015 ialah lebih menfokuskan bagaimana menggerakkan kader anggota partai DPRD untuk membantu pasangan calon yang didukung oleh Nasional Demokrat (NasDem); 2) Menfokuskan kualitas kinerja kader dalam melayani dan menampung aspirasi dari masyarakat; 3) Partai Nasional Demokrat (NasDem) merupakan partai baru eksis dalam kancah politik tanah air sehingga koordinasi yang baik dan komunikasi efektif, sehingga kader-kadernya masih bersih dan belum ada yang tersangka dengan kasus korupsi sehingga menjadi trans positif dalam menjalankan pilkada serentak 9 Desember Tahun 2015.; 4) Kekuatan partai Nasional Demokrat (NasDem) menghadapi pilkada serentak, yang berlangsung 9 Desember Tahun 2015 ketika memberi dukungan berapa saja kursi partai Nasional Demokrat (NasDem) tidak meminta mahar dan melakukan pilkada serentak yang sehat sehingga menghasilkan pemimpin dan pejabat-pejabat yang sehat dan murni; 5) ketika memberi dukungan beberapa kursi partai Nasional Demokrat (NasDem) tidak meminta mahar walaupun banyak serentak, karena tugas partai Nasional Demokrat (NasDem) melakukan pilkada sehat sehingga melahirkan pemimpin yang murni sesuai dengan visi dan misi.

Partai Nasional Demokrat (NasDem) yang tercatat menjadi peluang terbesar dalam memenangkan pilkada tahun 2015 di Provinsi Sumatera Utara adalah sebagai berikut: 1) Adapun peluang partai Nasional Demokrat (NasDem) dalam menghadapi pilkada serentak tahun 2015 ialah menerima peluang dan dukungan dari pihak luar 53\%, ini merupakan motivasi dan peluang besar bagi Nasional Demokrat (NasDem) dalam menyiapkan sebuah strategi; 2) Keberadaan partai Nasional Demokrat (NasDem) sebagai partai baru yang mampu berkembang pesat, khusushnya di Provinsi Sumatera Utara yang hampir merata di setiap Kabupaten/Kota yang ada di Provinsi Sumatera Utara sehingga konstituen sudah sangat mengat mengenal partai Nasional Demokrat (NasDem); 3) Ancaman
(kekurangan)

Beberapa hal yang tercatat sebagai ancaman partai Nasional Demokrat (NasDem) untuk memenangkan pilkada serentak ada dua hal yakni berasal dari faktor internal (dalam) dan faktor eksternal (luar). Adapun beberapa yang menjadi ancaman adalah sebagai berikut: 1) Faktor internal: a) Tidak solidnya para anggota kader pengurus Kab/Kota dalam memilih caleg partai Nasional Demokrat (NasDem) dari setiap anggota partai tersebut; b) Dalam pemilu peraturan bagi setiap anggota partai mememperoleh suara terbanyak adalah pemenangan yang akan duduk sebagai anggota legislatif, sehingga mengakibatkan persaingan yang sangat kuat antara sesama caleg partai Nasional Demokrat (NasDem) tersebut.

2) Faktor eksternal; dengan banyaknya partai-partai lama dan persaingan yang ketat terkhusus dengan PDI-P, dan Golkar yang selalu menjadi ancaman serius untuk pencapaian suara yang sangat signifikan bagi partai Nasional Demokrat (NasDem): a) Sumber daya manusia yang terburu-buru di rekrut sehingga tidak sempat dilatih bagaimana kinerja tentang berpolitik yang sesuai dengan prosedur sehingga mendapatkan hasil yang tidak sesuai/tidak maksimal sesuai dengan prosedur perpolitikan; b) Beberapa hal yang tercatat sebagai kelemahan yang paling mendasar di DPW Partai Nasional Demokrat (NasDem) untuk memenangkan pilkada serentak adalah sebagai berikut: a) adapun kelemahan partai Nasional Demokrat (NasDem) dalam menghadapi pilkada serentak tahun 2015 di Sumatera Utara ialah bagaimana kesanggupan partai Nasional Demokrat (NasDem) untuk mendapatkan dukungan $20 \%$ dari setiap daerah dengan dukungan partai lain untuk berkoalisi dengan setiap kader. Sumber : (hasil wawancara dengan sekretaris Ganda Manurung ST. M. BA).

Berdasarkan analisis peneliti dengan menggunakan analisis SSWOT, dapat di ketahui bahwa kekuatan, kekuatan, peluang, kelemahan dan ancaman partai Nasional Demokrat (NasDem) dalam Pilkada Serentak Tahun 2015 tidak memiliki kesulitan yang cukup signifikan, sehingga partai Nasional Demokrat (NasDem) tetap bisa menjalankan strategi yang cukup baik demi kemajuan dan 
Roslinda Wati Malau, Muhammad Aswin Hasibuan \& Irwan Nasution, Strategi Partai Nasional

perkembangan Indonesia yang jauh lebih baik khususnya dalam menampung dan menyalurkan aspirasi masyarakat.

\section{SIMPULAN}

Strategi Dewan Pimpinan Wilayah partai Nasional Demokrat (NasDem) (DPW) dalam pilkada serentak tahun 2015 didasarkan atas dasar kekuatan yang terorganisir, perencanaan yang di lakukan melalui dari tahapan penjaringan calon legislatif, koalisi, dan komunikasi yang baik dengan masyarakat. Dengan penentuan wilayah bagi seorang caleg yang berdasarkan survey independen partai Nasional Demokrat (NasDem) dengan analisis SWOT yang di lakukan untuk mengetahui kekuatan, kelemahan, peluang, dan ancaman bagi partai Nasional Demokrat (NasDem), serta kemampuan partai Nasional Demokrat (NasDem) berkomunikasi dengan politik dalam melakukan pendekatan terhadap tokohtokoh penting yang berpengaruh di tengahtengah masyarakat, dan kemampuan partai Nasional Demokrat (NasDem) dalam berkomunikasi untuk mencitrakan diri sebagai partai yang pro dengan masyarakat.

\section{DAFTAR PUSTAKA}

Arifin, A. (2015). Perspektif Ilmu Politik. Jakarta : Komisi Pemilihan Umum.

Budiardjo, M. (2008). Dasar-dasar Ilmu Politik. Jakarta. PT. Gramedia Pustaka Utama.

Buku pedoman Partai Nasional Demokrat (NasDem) SK DPP NOMOR : SKEP-004/DPPNasional Demokrat (NasDem)/ll/2013 Tanggal 20 Februari 2013".
Departemen Pendidikan Nasional. (2010). Kamus Besar Bahasa Indonesia. Jakarta Gramedia Pustaka Utama.

Gatara, S. (2007). Ilmu Politik Memahami dan Menerapkan. Bandung. Pustaka Setia.

Hadi, S, (1887). Methodologi Reasarch. Yogyakarta : Yayasan Penerbit Psikologi UGM.

Hermawan, W, (1992). Pengantar Metodologi Penelitian : Buku Panduan Mahasiswa, Jakarta : PT. Gramedia Pustaka Utama.

http:m.merdeka.com/profil/indonesia/p/partai Nasional Demokrat (NasDem) di akses tanggal 20 Maret 2016.

Idrus, M. (2009). Metode Ilmu Sosial Pendekatan Kualitatif. Jakarta. PT. Glora Aksara Pratama.

Mz Hollyson, R. \& Sari, S. (2015). Pilkada. Jakarta : Pilkada Serentak.

Nazir, M. (2003). Metode Penelitian Kualitatif. Jakarta: PT Ghalia Indonesia.

Pamungkas, S. (2012). Partai Politik. Yogyakarta. PT. Perum Griya Saka Permai.

Sinaga, R.S. (2013). Pengantar Ilmu Politik. Yogyakarta : GRAHA ILMU.

Suhardi, (2003). Politik Sosisl Modern, Dasar dan Directiva. Jakarta : yayasan Karya Dharma IIP.

Suharyanto, A., (2014). Partisipasi Politik Masyarakat Tionghoa dalam Pemilihan Kepala Daerah, Jurnal Ilmu Pemerintahan dan Sosial Politik, 2 (2): 166-175

Surjaweni, V.W. (2014). Metode Penelitian. Yogyakarta : Penelitian Kualitatif.

UU No. 32 Tahun 2004 Tentang Pemilukada

UU No. 8 Tahun 2015 Tentang Pilkada

UU No.2 Tahun 2008 Tentang Partai Politik

Asal-usul-motivasi.blogspot.co.id/2014/01asal-usulsejarah-partainasional.html?m:1. 